\title{
THE FUTURE ROLE OF AGRICULTURE IN MULTIFUNCTIONAL RURAL DEVELOPMENT
}

\author{
Elena Kovtun, Kateryna Gnatyshak, Lyudmyla Chornenka \\ Faculty of Agricultural Management \\ National University of Life and Environmental Sciences of Ukraine
}

\begin{abstract}
This paper is focused on analysis and evaluation of the future role of agriculture in multifunctional rural development in Ukraine and also reviewing of the significant basic factors which have influence on it.
\end{abstract}

Key words: multifunctionality, rural development, agricultural potential, Ukraine

\section{Introduction}

Multifunctionality has progressively become a central component of modern agriculture. Multifunctionality in agriculture is generally defined as pointing to the benefits of farming rather than just producing food. Some of these benefits include but are not limited to the increase of food and environmental quality, production of bio-energy, facilitating recreation and tourism, and sustaining a viable habitat for animal welfare. Proponents of multifunctionality also purport that it also is responsible for shaping the landscape and positively effects social and cultural systems. In essence, a combination of all these benefits fundamentally contributes to a country's economic growth. It has not been long since this concept was introduced in the country, yet, it quickly found numerous followers. In order to discuss the role of agricultural multifunctionality in the rural development, it becomes imperative to discuss its three main dimensions, namely economical, social and environmental. The economical aspect of the agricultural multifunctionality embraces the characteristics of Ukraine's current agricultural status.

\section{Results and Discussion}

Ukraine occupies an area of 603,67 square $\mathrm{km}$ and is one of the largest European countries being the home to 46,2 million people. Ukraine is a land of wide, fertile agricultural plains, with large pockets of heavy industry in the east. Ukraine's agricultural sector represents an essential part of the country's economy. Throughout Ukraine's history agriculture has played a dominant role in the development of rural areas and in the shaping of rural landscapes. After the collapse of Soviet Union, the situation in the Ukrainian economy as well as in the agriculture started worsening from year to year, which resulted in weakening of Ukraine's leading position on the world agricultural arena and in the lost of its huge profits gained due to the effective development of agriculture. Ukraine lost a lot of effective production technologies during 1991-2006, what made a negative impact on the development of the country's agriculture and economy in general. However today, agriculture still remains a key economic activity and vital aspect of the creation of wealth and employment in many rural areas.

Ukraine possesses a significant amount of arable lands and therefore the majority of the national lands are suitable for crop production. Arable lands account for more than half of Ukraine's total land area (Table 1). Of this, agricultural land covers approximately $69 \%$ or 41,7 million hectares of its territory. The largest areas of agricultural lands are concentrated in the Central and Southern parts of Ukraine (Chernigiv, Poltava, Dnipropetrovsk, Kharkiv, Zaporizhzhya, and Odessa regions). Taking into consideration that the most fertile black earth covers $60 \%$ of Ukraine's area, the land resources represent one of the country's most valuable assets.

Table 1. Land distribution by their type as of January 1, 2008 (in 1000 ha)

\begin{tabular}{|l|r|}
\hline All lands, total & $\mathbf{6 0 3 5 4 , 8}$ \\
\hline Agricultural lands, total & 42868,7 \\
\hline Including farm lands, total & 41650,0 \\
\hline Including: & \\
\hline Arable Lands & 32433,7 \\
\hline Fallow lands & 383,9 \\
\hline Perennials & 899,0 \\
\hline Hayfield lands & 2419,8 \\
\hline Pastures & 5513,6 \\
\hline
\end{tabular}

Source: Ministry of Agrarian Policy of Ukraine

Through the property ownership reforms in the 1990s, the ownership rights of smaller lands farmed by large collective farms had to be returned to its local rural residents. However, the majority of these local residents faced some difficulties 
and was neither ready to farm these fragmented farmlands on their own because of financial constraints nor were they able to unite and form a more powerful business structures. Hence, farming of the lands was done on the basis of land lease meaning smaller farms were mainly rented to companies delegated on the basis of the former collective farms. Today, large agricultural enterprises comprise a higher percentage of arable land than compared with smaller individual farm households. These individual farms use substantial portion of its land for hay production and for orchards. The structure of current land use in Ukraine is shown in Table 2.

Table 2. Farm Land Use as January 1, 2009, (in 1000 ha)

\begin{tabular}{|l|c|c|}
\hline & $\begin{array}{c}\text { Farm } \\
\text { lands }\end{array}$ & $\begin{array}{c}\text { Including } \\
\text { arable lands }\end{array}$ \\
\hline Total Ukraine & 42844,8 & 32473,4 \\
\hline Including: & & \\
\hline Rural residents (individual households) & 15604,0 & 11374,6 \\
\hline Agricultural enterprises & 17252,2 & 15695,4 \\
\hline Private family farms & 4031,9 & 3817,0 \\
\hline
\end{tabular}

Source: State Statistics Committee of Ukraine

According to the data of Ministry of Agrarian Policy of Ukraine, in 2007 over 14,9 thousand agricultural enterprises of various organizational forms were engaged in the economic activity, among them were 7,4 thousand economic partnerships, 4,2 thousand private enterprises, 1,3 thousand production cooperatives, 0,36 thousand state enterprises, 1.6 thousand enterprises of another incorporation forms. To assure equity and enforcement the functioning of those entities is regulated by the Law of Ukraine "About Economic Partnerships", "About Agricultural Cooperation", "About Enterprises" and by the number of the other legislative acts. These agricultural enterprises retain 17,5 million agricultural lands for their use, mostly attracted through lease of the peasants' land shares. If classified by the area of land use, agricultural enterprises remain the largest of all agrarian entities. The average land use size in one enterprise constitutes 1200 hectares. Additionally, during the years of reforms farms have become an integral component of the rural economy. Organizational and legal principles of their operation are regulated by the Law of Ukraine "About Farming Enterprises" (2003). At present the number of farmers in Ukraine approximates to 135000 persons. 43 thousand of farms plant about 3,7 million hectares of agricultural land. On the average, one farm cultivates 85 hectares and $50,4 \%$ of farms cultivate the areas of more than 500 hectares.

Currently, Ukraine contains nearly five million individual peasant households which operate nearly 15,7 million hectares of agricultural lands. Individual households have become a stabilizing factor of employment for persons leaving agricultural enterprises. The number of persons involved in individual households reaches 3 million people. Individual peasant households started an effort at revitalization after the CMU Decree "About Land Plot
Privatization" which was approved in 1992. Prior to this Law, land plots were transferred for free into private ownership in order to run individual households. Maximal size of such plots was increased to 2 hectares. Further expansion in size of such households was affected through the addition of land plots received as the land shares during reformation of collective agricultural enterprises. Organizational and legal framework for individual peasant household operation is regulated by the Law of Ukraine "About Individual Peasant Households" (2003).

All these agricultural organizational entities face a challenge to operate efficiently based on the outdated agricultural infrastructure. However, there have been some progress on their pace of improvement the technical base of the Ukrainian agriculture. Agricultural enterprises are gradually increasing investment into fixed assets, thus outrunning the industry sector and the economy in the whole by the increment rate. Although the portion of buildings, structures and transmitting devices in the agricultural fixed assets has decreased, the portion of modern machinery, equipment and means of transportation has grown. Thus, the Ministry of Agrarian Policy of Ukraine provides the following information: in 2007 the stock of machinery and tractors in agricultural enterprises contained 182,5 thousand of tractors (10 pieces per 1000 hectares of arable land); 44,3 thousand of grain combine harvesters (4 pieces per 1000 hectares of grain crop acreage without corn); 7,7 thousand of beet harvesters (15 pieces per 1000 hectares of beet crop acreage); 4,2 thousand of corn harvesters ( 7 pieces per 1000 hectares of corn crop acreage). Power capacity in agricultural enterprises reached nearly 5932 million h.p. (322 h.p. per 100 hectares of crop acreage). Individual farmer and other households due to their smaller production volumes possess less machinery, namely 150,1 thousand tractors and 16,5 thousand harvesters.

The labor force in the Ukrainian agricultural accounted for 3,6 million people in the year 2007. The number of farmers approximates to 135 thousand persons and those, involved in individual households reaches 3 million. However, Ukrainian farmers play far more important role to Ukrainian society than just work in within the agri-industrial complex. Sometimes farmers are considered to be the

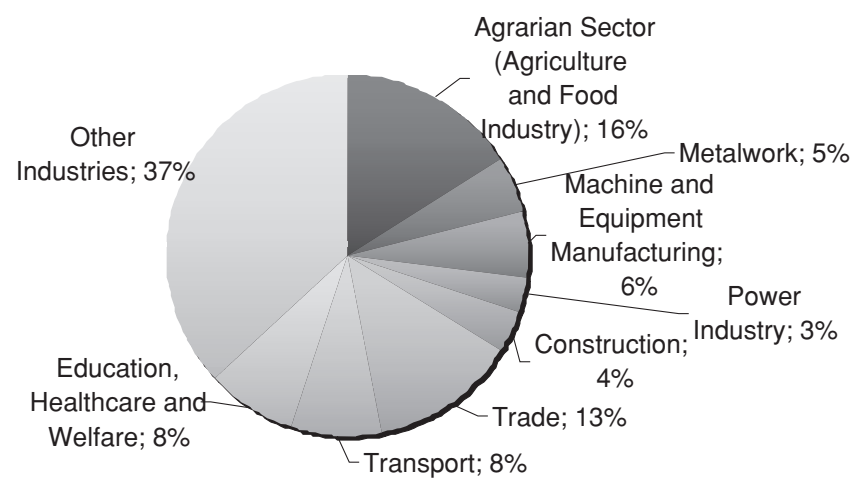

Figure 1. Agrarian Sector in Gross Domestic Product (GDP) of Ukraine Source: Ministry of Agrarian Policy of Ukraine 
guardians of rural customs and traditions and of an age-old way of life. The rural customs and traditions continue to be passed on to future generations through the farming population, but they can also be perpetuated through clubs and cultural associations whose non-farm members share a profound appreciation of traditional rural values.

Ukraine's agricultural sector makes a significant contribution to the national economy. The input of agri-food sector to the GDP equals to such important industries as metallurgy, machine building, power and construction all together (Figure 1).

During 2007 agrarian enterprises paid taxes and dues to the consolidated budget totals 10.4 billion UAH or 2,2 times more in comparison with 2000. In particular, agricultural sector revenue was almost 1.4 billion UAH or 2,4 times more than the figure of 2000 .

Introduction of market changes to the Ukraine's agrarian sector had a positive impact on the dynamics of the country's agricultural production. Since 2000 in all categories of agricultural entities a gradual increase in the gross output volumes of agricultural production had been observed (Figure 2).

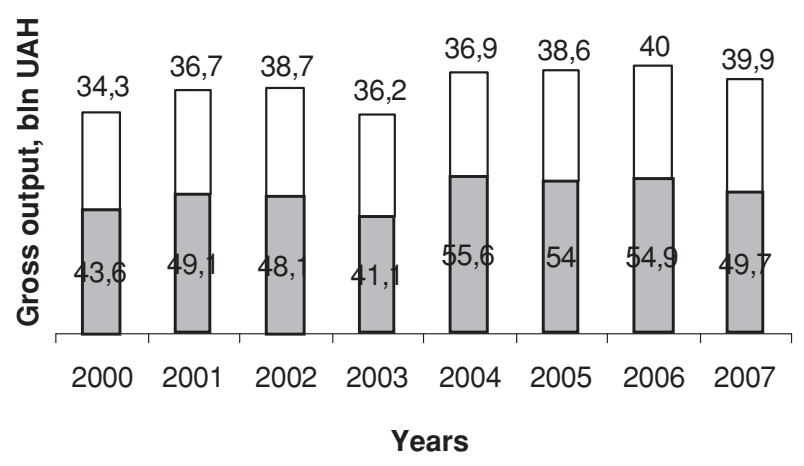

Plant raising $\square$ Cattle Breeding

Figure 3. Gross Output of Agriculture, bln. UAH (against the 2005 prices) Source: Ministry of Agrarian Policy of Ukraine

As previously mentioned, in 2008 the volume of agricultural production has slightly increased in comparison with the previous years and reached 150,8 billion UAH. Gross output of plant crops is provided by agricultural enterprises and individual households in the proportion 1:1,2 and more. Agricultural enterprises are the major supply forming subjects at the grain, sunflower and sugar beet markets, while individual peasant households prevail at the potato, fruit and vegetable markets. In 2000-2006 over $70 \%$ of cattle breeding products were provided by individual peasant households. They play the leading role in supply formation at the milk, beef and pork markets. At the same time, production balance between individual households and agricultural enterprises is gradually changing in favor of the latter. In 2007 agricultural enterprises increased manufacturing of cattle breeding products by $7,1 \%$, while individual households reduced the production by $7,3 \%$. Agricultural enterprises account for nearly $70 \%$ of the poultry meat production. The reason is the increasing importance of the agricultural production effectiveness and its innovative character. Thus, in 2008 in the agricultural enterprises of all types of ownership the volume of production has increased for $1,5 \%$, and in the individual farm households - decreased for $1 \%$. Regardless of the numerous positive figures in the preceding examination, in the time of current economical crisis, the agri-industry needs state support even more than before. Ukrainian agriculture enjoys a significant fiscal support from the state coming in a form of Budget expenditures and Tax expenditures (tax privileges, tax arrears, and tax write-offs).

The current trend shows agriculture is growing in terms of government expenditure and industry revenue.

The total fiscal support to agriculture and rural areas grew almost threefold, fluctuating around $2 \%$ of Ukraine's GDP. This figure has been much higher in Ukraine, since significant non-fiscal measures benefit domestic agricultural producers as well. In the 2007 budget of Ukraine financing of agriculture grew 2,8 times in comparison with 2003 and constituted 4,5 billion UAH. From this amount, nearly 812 million UAH were forwarded to maintain educational institutions and 97,2 million UAH to carry out scientific researches (Table 3). Within 2008 state support measures will become more sophisticated in line with the WTO requirements; however this will not impact negatively the total scope of support.

Table 3. Financing by the State Budget from the Ministry Expenses in 2003-2007, mln. UAH

\begin{tabular}{|l|c|c|c|c|c|}
\hline Expenses & $\mathbf{2 0 0 3}$ & $\mathbf{2 0 0 4}$ & $\mathbf{2 0 0 5}$ & $\mathbf{2 0 0 6}$ & $\mathbf{2 0 0 7}$ \\
\hline $\begin{array}{l}\text { Ministry of Agrarian } \\
\text { Policy total }\end{array}$ & 2291,8 & 2476,0 & 4887,3 & 6278,3 & 7952,0 \\
\hline including: & 1608,9 & 1614,4 & 2246,0 & 3057,9 & 4556,1 \\
\hline Agriculture & & 540,5 & 753,1 & 2017,0 & 2313,0 \\
\hline out of them: & & 95,4 & 415,1 & 333,5 & 551,3 \\
\hline $\begin{array}{l}\text { Support to } \\
\text { manufacturing } \\
\text { products of cattle } \\
\text { breeding and crop } \\
\text { planting }\end{array}$ & 270,8 & 341,2 & 523,3 & 667,4 & 811,8 \\
\hline $\begin{array}{l}\text { Financial support to } \\
\text { agribusiness through } \\
\text { cheap loan mechanism }\end{array}$ & 281,5 & 20,9 & 56,5 & 63,5 & 37,6 \\
\hline Education & 130,6 & 499,5 & 2061,5 & 2489,5 & 2546,5 \\
\hline Science & & & & & \\
\hline Other directions & & & & & \\
\hline
\end{tabular}

Source: Ministry of Agrarian Policy of Ukraine

The Ukrainian government provides financial support to the agriculture in other forms of direct and indirect subsidies. According to the existing in Ukraine practice the country, Ukrainian's government provides its support to the agricultural producers in different forms. An additional form of state support to agriculture come as a state financing of land plants development programs, cattle breeding and live stock breeding programs, fishery development programs, reclamation projects development and environmental 
programs, financial support to agricultural producers through special loans, gardening sector support programs, veterinary development and safety protection programs, agricultural science development, rural infrastructure development, rural sector's social infrastructure development programs, programs on support to producers of agricultural equipment, etc. Clearly, many of these traditional items, which are included into the list of the supporting measures, cannot be considered the agricultural subsidies. For example, rural infrastructure and social development programs as well as agricultural science development programs cannot be considered as those agricultural subsidies. However, other subsidies can be the subject of such agreement. In any case, it's crucially important to know the existing in Ukraine structure of state financial support to the agricultural sector with a breakdown on specific measures, in which this support is directed.

The total agricultural budget expenditures (TABE) are allocated through different ministries, e.g., Ministry of Agrarian Policy, Ministry of Finance, State Committee for Land Resources, etc., are the main source of direct and indirect subsidies. These monies grew from 1,47 billion UAH in 2002 to the planned UAH 6,68 billion for 2006. At the same time the share of TABE in total budget expenditures has been growing from $3,3 \%$ to $4,9 \%$ over 2002-2006. If we compare the dynamics of both types of expenditures to 2002 benchmark then total budget expenditures grew by 3,1 times in 2006, whereas TABE grew by 4,5 times over the same period. The ratio of tax proceeds from agriculture to TABE shows that the agriculture sector received almost two times more from the budget than contributed to it, which together with significant tax expenditures creates an imbalanced tax burden on Ukrainian economy, thus potentially decreasing whole economy competitiveness.

The highest weight in the total structure of the state support to agricultural sector has land plants development programs, which obtains $16 \%$ in the total amount of support. Those items, which are not subjects to the WTO regulations reclamation projects development and environmental programs $-12 \%$, programs on support to producers of agricultural equipment - 9\%, rural infrastructure development $9 \%$, agricultural science development $-6 \%$, veterinary development and safety protection programs $-3 \%$, rural sector's social infrastructure development programs $-2 \%$. All in total the non-related to WTO restrictions items accounts to some $41 \%$ of the total amount of subsidies coming to the Ukrainian agriculture. As on the state of 2004 the absolute amount of money, which was transferred for these six items accounts to around UAH 2 billion (USD 394 million), while the rest of the items, which can be considered as related to the WTO agreement items, was UAH 3,1 billion (USD 584 million).

Analyzing planning and execution of the state support programs over several years, one would definitely observe some important facts, revealing problems with budget expenditure planning. The existence of a particular program in a state agenda is not sustainable and lacks continuity. This reveals that Ukrainian government and Ministry of Agrarian
Policy in particular do not have a long-term strategy for use of the budget funds on agricultural and rural development, which reflects that Ukraine does not have any officially adopted strategy of agriculture and rural development yet. Budget programs are often underfinanced and not uniformly distributed over the whole year. This lack of strategy and erratic expenditures pattern makes long-term investment planning for agricultural enterprises in the sector very difficult and increases entrepreneurial risks.

However, the amount of agricultural subsidies to the Ukrainian producers (i.e., farmers) was rather virtual than real one. These were not transfers of the financial assets from the state budget to budgets of the producers. Although the state budget has been fixing the certain funds to be transferred as an agricultural subsidy it was almost never transferred to the final recipients (i.e., agricultural products producers) in a full amount. Final recipients of the agricultural subsidies were able to receive only a certain portion of the planned amount of subsidy. According to the data of the Ukrainian State Statistical Committee in 20012003 the average annual arrears on agricultural subsidies accounted some $36 \%$ of the planned amount of subsidy. This reflects the low level of fiscal discipline, which exists in the country and lack of financial resources, which government was planning to spend for subsidies.

Tax privileges remain one of the most used forms of Ukraine's state support to agriculture. They are huge compared to other sectors, exceeding even budget expenditures, should have compensated the lack of funds in a budget. However this was not the case. A bulk share of Ukrainian tax expenditures is excluded from WTO domestic support reduction commitments, meaning the absence of external leverage to eliminate them. Since the agrarian lobby is considerably strong in Ukraine, it is very likely that tax privileges for agriculture will persist in the future. Unfortunately, agriculture contributes much less to the budget than it gets from it, thus creating a tax burden bias in Ukrainian economy. Fiscal support, from an economic point of view, should leverage government policies to increase productivity and competitiveness of the agriculture and food value chain. If the efficiency of fiscal support is neglected and dominated by the influence of particular lobby groups in specific sub-sectors, the impact of fiscal support can become negative. Relying heavily on different production subsidies, however the Ukrainian government ignores efficiency and productivity as an objective for agricultural policy. Instead, the government pursues the goal of food self-sufficiency by increasing output utilizing high subsidies, import tariffs and non-tariff barriers. Therefore policymakers try to sustain existing farm structures and procedures of granting aid and tax privileges to producers. Fiscal support is designed so as to stimulate large agricultural producers, for whom it is much easier to get financial assistance from the budget than for private farmers, for example. Finally, agricultural policy makers implicitly rely on agricultural producers in providing social services in rural areas and their development, thus delaying structural reforms in the sector. 
The next point which should be outlined within this paper is Ukraine's agricultural production and trade during the period of increasing world food prices, or in other words, in the frameworks of global financial and economic crisis. The world food crisis both poses challenges and presents opportunities for Ukraine. The solution to the challenges lies in the appropriate macroeconomic policies and targeted social support, not in the interventions on the food market. Measures to protect the poor and vulnerable from the food price increases need to be separated from agricultural market policy, so that Ukraine can seize the emerging opportunities:

An appropriate agricultural policy framework and public investment program would provide incentives for private investments so needed to build Ukraine's export-oriented and competitive agriculture sector. An increase of productivity in agriculture would also make Ukraine less vulnerable to possible low harvests. Ukraine's accession to the WTO and the beginning of negotiations on a free trade agreement with the EU provides key impetus to the required reforms, and the Ministry of Agricultural Policy of Ukraine has already taken several initial steps.

Some key reform and investment areas include:

- trade policies (including refraining from export restrictions);

- transportation, storage;

- market information infrastructure and agricultural statistics;

- institutional framework for land market;

- access to finance and risk management instruments;

- research and extension, and vocational training of agricultural specialists and farm managers;

- veterinary and food safety control system compliant with regulations in target markets.

The negative impact of the increasing domestic food prices as a result of global food crisis should be cushioned by targeted social assistance programs, complemented with tighter macroeconomic management to reduce overall inflation. Ukraine already operates a number of targeted social transfer systems that are quite efficient at identifying and supporting the most vulnerable subjects. For instance, the "last resort" program for the very poor has a targeting efficiency of $73 \%$ among the poorest population. Support to single mothers and to young (0-3 years) children is also effective. These programs could be scaled up to support those most affected by rising food prices. This would be cheaper and more sustainable than the blanket increases in all social payments implemented in recent years. At the same time, numerous benefits that do not effectively target the poor, such as housing subsidies, could be scaled back.

In order to help national economy to overcome the crisis, the Ukrainian government created a number of state programs that support the agricultural sector. Some of these programs are briefly discussed next.

The Government of Ukraine has established a program for the 'Agroindustrial Complex and Development of Rural Areas' which, if implemented, would make a significant contribution to escalate the sectoral competitiveness and reduce disparities between the rural and urban areas of Ukraine. This program is based on the three pillars: rural development, competitiveness of agriculture, including quality and safety issues, and natural resources management and environmental sustainability. It includes provisions for the improvement of social and physical infrastructure in the rural areas of Ukraine, for the development of key markets associated with agriculture (finance, land, insurance), for the adoption of international food safety and quality standards, for a transition to efficient mechanisms of state support (decoupled payments), and for enhancement of efficiency in agricultural based on innovations and knowledge transfers.

On the other hand, the Ministry of Agricultural Policy of Ukraine has prepared an advanced draft of a national program for rural development until 2015. Citing relevant laws such as the Law of Ukraine "On basis principles of national agrarian policy for the period until the year 2015", the Law of Ukraine "On state support for the rural economy of Ukraine", and the Law of Ukraine "On the priority of the development of rural space and agro-industrial sector in the national economy", MAP has prepared a detailed draft of a national program aiming at improving Ukraine's competitiveness on domestic and foreign markets, ensuring food security for the country, and the preservation of rural way of life and peasantry as the carrier of Ukrainian identity, culture, and spirituality.

If implemented effectively and timely, the above mentioned measurements can create favorable conditions for the recovery of both the agricultural sector and the national economy as a whole. But there are still some other factors which should be taken into consideration in order to fasten the process of the economic revival in Ukraine.

First of all, public and private investments are particularly needed to improve the efficiency of the marketing systems of agricultural products. Even if spreading of excessive price on agricultural goods due to export restrictions was completely eliminated, farmers in Ukraine would still get less for their products than their counterparts in other countries because of the high marketing costs.

Another policy priority is a completion of institutional arrangements for the property rights registration (including land) and removal of the moratorium on land sales. Land purchase and sale would not lead to rapid, dramatic changes, but it would set in motion a virtuous circle whereby the availability of collateral increases investment and productivity in agriculture, which in turn leads to the increase in land values, which makes yet more collateral available, and so on. It would also, together with the enforcement of bankruptcy procedures in agriculture, increase the pressure on less efficient farmers to leave production and make the resources that they have been using poorly available to other more efficient farmers. One of the largest handicaps that Ukraine's agriculture has to face is the persistence of a very high proportion of highly inefficient farms, many of which are subtracting rather than adding value as they produce.

Compliance with international quality standards will be critical for Ukraine's further integration into the global 
economy. Ukraine has recently completed its lengthy negotiations on WTO accession, and has entered into negotiations with the EU on a free trade agreement (FTA). The extent to which Ukrainian agriculture benefits from WTO membership and a FTA with the EU hinges on its ability to comply with international quality standards. For example, Ukraine is currently able to export most livestock products (meat, milk) to only a small number of mainly former Soviet countries. If agronomic practice and product quality do not comply with market requirements and internationally recognized guidelines and standards, it will result in the lower quality products for domestic consumers (food safety), delays in completion of trade agreements, and in the inability to access to high-quality-high-price foreign (and domestic) markets.

The Ukrainian government has also to revise country's handling, storage and transportation infrastructure. Ukraine's agricultural market and supply chains continue to be characterized by significant post-harvest losses, high transaction costs, and in transparent price formations due to the information asymmetries. This leaves producers with unnecessary unfavorable deals and limited marketing options, causing further low farm-gate prices and hence creating disincentives for private investments in agriculture. It also increases consumer prices. Public investments, especially in to the infrastructure with public good characteristics, such as road and rail networks, waterways, can intensify the competition by reducing regional market power, and therefore can act as an important catalyst for private investment in other links of the supply chain. For example, incentives to expand on-farm storage capacity (which would enable farmers to avoid being forced to sell products into the post harvest glut markets) depend on reliable, low cost transport channels to more than one possible purchaser.

And finally, Ukrainian agriculture urgently needs centers of excellence in higher education and research to produce future agribusiness leaders, analysts and experts in administration, who will form the human resources needed to ensure the steady growth of Ukraine's agroindustrial complex and its economy as a whole.

The characteristics and issues of the Ukraine's agricultural sphere described its economical role in the multifunctional rural development. The next dimension of multifunctionality is presented by the social function of agriculture. Despite numerous positive trends in the economic matters of agriculture, the examination of its social aspect revealed a number of problems that rural areas are facing today. Regardless of the general positive tendency of increasing wages and reduction of the poverty in the entire country, rural areas remain the milieu with the highest level of poverty. This fact presents a real problem for the country, since more than $30 \%$ of the Ukrainian population permanently lives in the countryside (Table 4).

Disparity in the material status of the rural residents is best uncovered by their expenditures. Thus, in 2007 total consumptive spending of one rural resident were $20,1 \%$ lower than those of an urban resident and accounted for 566,92 UAH per month (in comparison to 709,95 UAH similar spending of urban residents).

Table 4. Correlation between the urban and rural population in Ukraine in 2005-2009

\begin{tabular}{|l|c|c|c|c|}
\hline \multirow{2}{*}{ Year } & \multicolumn{2}{|c|}{ Urban Residents } & \multicolumn{2}{c|}{ Rural Residents } \\
\cline { 2 - 5 } & mln persons & $\%$ & mln persons & $\%$ \\
\hline 2005 & 32,0 & 67,7 & 15,3 & 32,3 \\
\hline 2006 & 31,9 & 68,0 & 15,0 & 32,0 \\
\hline 2007 & 31,8 & 68,1 & 14,8 & 31,9 \\
\hline 2008 & 31,7 & 68,3 & 14,7 & 31,7 \\
\hline 2009 & 31,6 & 68,5 & 14,6 & 31,5 \\
\hline
\end{tabular}

Source: State Statistics Committee of Ukraine

After 9 months of 2008 the average total spending of a rural resident was still lower than its equivalent of an urban resident, and reached 2203 UAH against 2743 UAH, which is $19,7 \%$ difference. Life conditions in the rural areas are also complicated by the absence of necessary road network and telecommunication systems (more $1 / 4$ of the rural settlements do not have bus stops, only $44,5 \%$ have asphalt roads, only $7,3 \%$ have street lights); appropriate water supply $(134,3$ thousand rural residents do not have permanent access to water), few social-cultural entities (70,3\% of villages do not have kindergartens, $51,1 \%$ - schools, $58,8 \%$ - post offices, $33,2 \%$ - hospitals). During the years of administrative economy agricultural enterprises were responsible for development and functioning of the social infrastructure objects. Today mission of these enterprises that are participants of market relations does not include protectionism of the social sphere. However, satisfactory condition and availability of social sector would have fostered development of commercial activities in the rural areas, improved socio-demographic situation, etc. Problems mentioned above caused another negative tendency in the rural area which is the ongoing shrinkage of the number of rural settlements. In the beginning of 2006 there were 28,57 thousand villages in Ukraine. 227 of them, which is $0,8 \%$ from the total amount, did not have any population left. Quantity of the rural communities with population less than 50 persons accounted for $13,8 \%$ of the total amount. Therefore, rural areas in Ukraine have traditionally been associated with underdevelopment and backwardness. A major share of young rural generation strives to migrate to urban areas in pursuit of a "better life" in the form of better facilities, social and physical infrastructure, etc.

The next component in analyzing the social status of Ukraine's rural areas is to describe major trends in the rural employment. As indicated in Table 5, a significant share of the rural population is engaged in agriculture (about 10\%), but approximately the same share is employed in non-farm sector (education, healthcare, extracting industry, etc). On the other hand, approximately $71 \%$ of the rural population is non-employed. These include those seeking work but not able to find it (unemployed), pensioners, pupils, students etc. 
However, one should take into account the specifics of rural life in Ukraine. Most rural households, including those involved in nonfarm sector, tend to spend a considerable amount of time on subsistence or subsidiary farming as well. For example, rural, households produce about $2 / 3$ of Ukraine's total raw milk production. Moreover, according to official statistics, households produce about $60 \%$ of the gross agricultural produce of Ukraine. The rural non-farm employment profile is more or less similar across all regions.

Table 5. Sectoral profile of rural employment of primary occupation in Ukraine, $2004, \%$

\begin{tabular}{|c|c|c|c|c|c|c|c|}
\hline & Branch of activity & Ukraine & West & North & Center & South & East \\
\hline \multirow{16}{*}{ 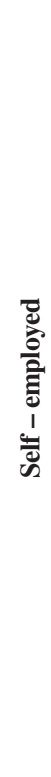 } & Agriculture & 9,27 & 4,76 & 11,09 & 9,92 & 13,58 & 10,48 \\
\hline & Fishery & 0,11 & 0,09 & $*$ & 0,03 & 0,16 & 0,23 \\
\hline & Extracting industry & 0,50 & 0,38 & 0,25 & 0,40 & $*$ & 1,82 \\
\hline & Processing industry & 2,12 & 2,63 & 2,46 & 2,07 & 0,83 & 2,05 \\
\hline & $\begin{array}{l}\text { Electricity, gas and } \\
\text { water supply }\end{array}$ & 0,62 & 0,71 & 0,86 & 0,58 & 0,42 & 0,89 \\
\hline & Construction & 1,55 & 1,68 & 1,28 & 0,99 & 2,56 & 1,29 \\
\hline & Whole- and retail sale & 1,95 & 1,74 & 2,43 & 1,65 & 156 & 2,65 \\
\hline & Hotels & 0,25 & 0,39 & $*$ & 0,33 & 0,29 & 0,18 \\
\hline & $\begin{array}{l}\text { Transport and } \\
\text { communication }\end{array}$ & 1,60 & 1,11 & 2,64 & 1,84 & 1,67 & 1,52 \\
\hline & Finance & 0,13 & 0,12 & 0,15 & 0,04 & 0,25 & 0,15 \\
\hline & Real estate & 0,04 & 0,05 & $*$ & 0,10 & 0,03 & 0,07 \\
\hline & State government & 2,07 & 2,56 & 1,91 & 2,53 & 1,71 & 1,79 \\
\hline & Education & 3,83 & 4,05 & 3,59 & 3,35 & 4,29 & 3,22 \\
\hline & Healthcare & 2,05 & 1,96 & 3,17 & 2,08 & 1,85 & 1,73 \\
\hline & Public services & 0,45 & 0,55 & 0,29 & 0,37 & 0,86 & 0,13 \\
\hline & Servants & 0,01 & 0,03 & $*$ & $*$ & $*$ & $*$ \\
\hline \multicolumn{2}{|c|}{$\begin{array}{l}\text { Non-employed (pensioners, } \\
\text { pupils, students, } \\
\text { unemployed, } \\
\text { children, etc) }\end{array}$} & 73,43 & 77,07 & 69,85 & 73,71 & 69,94 & 71,76 \\
\hline
\end{tabular}

Note: $*$ no records

Source: Calculation of Institute for Economic Research and Policy Consulting in Ukraine on the basis of household survey conducted by the State Statistics Committee of Ukraine in 2004

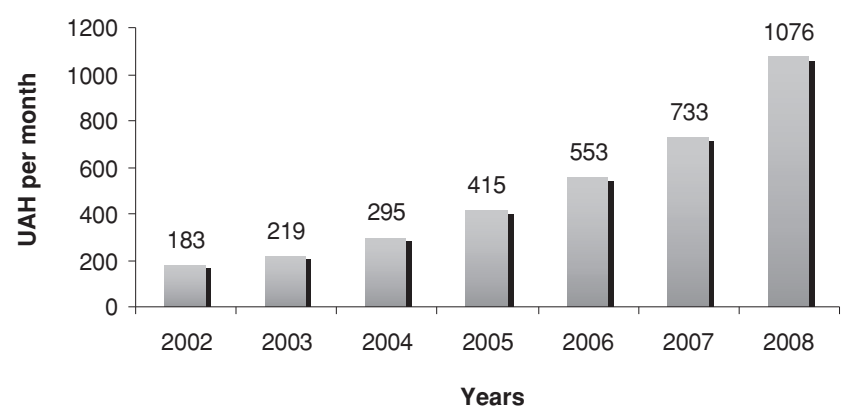

Figure 3. Dynamics of the average monthly salary of agricultural workers, UAH

Source: State Statistics Committee of Ukraine

The most popular sectors, in terms of rural employment, are the food processing industry, wholesale and retail trade, transport and education. The relative importance of employment in agriculture largely reflects the degree of regional agriculture specialization. For example, in the leading Southern and Eastern regions higher percentages of the rural population are employed in agriculture than in other regions.

Agricultural production in Ukraine remains the economic activity with the lowest level of wages. According to the information of the Ministry of Agrarian Policy in January November 2007 average monthly salary of an agricultural worker account $712,2 \mathrm{UAH}$ or $54 \%$ of the average salary rate among all sector of economy. In 2008 it did grow for $95 \%$, but stayed among the lowest if compared to the other industries (Figure 3).

Taking into account the fact that the majority of rural inhabitants are employed in agriculture, low wage together with other economic factors, such as high unemployment, poor living and working conditions, appear to be the key factor which forces them to look for a better place of work not only in urban areas of Ukraine, but also in foreign countries. The official data provided by Ukrainian Ministry of Statistics has proved this fact, indicating that net migration is positive only in urban areas while it is very negative in rural ones (Figure 4). In 2007, for example, migratory growth in cities and towns was equal to 0,3 people per 1000 inhabitants whereas the number of dwellers in countryside decreased by 1,7 per 1000 population due to intensive external migration.

Realizing the importance and depth of the aforementioned issues, Ukraine's government makes an effort to revitalize the area and help its dwellers through its policy and programs.

Thus, state policy in social and economic development of rural settlements includes such objectives as promotion of policy implementation for integrated development of the rural locality by means of close cooperation between governmental agencies, local self-governments, rural communities, NGOs and private sector. Ukraine's authorities try to introduce mechanisms for partnership and support to rural social area development by the state and

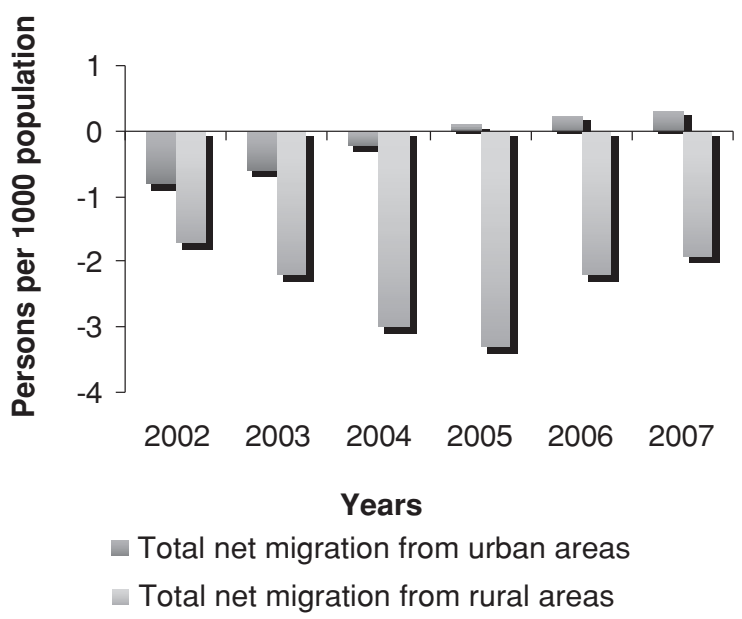

Figure 4. Total net migration (external and internal) in urban and rural areas of Ukraine (persons per 1000 population)

Source: State Statistics Committee of Ukraine 
local budgets, enterprises and organizations located within the rural territories, in line with the programs of community social and economic development. The government also strives to improve the quality of life in rural localities, personal enhancement by approximating the quality of education, medical and cultural services, living conditions and rural infrastructure to the urban one. Government's expenditures on rural development in includes following several state programs, managed by Ministry of Agrarian Policy of Ukraine and other ministries: state privileged crediting of individual rural builders; restructuring and development of public utilities in rural areas; development of physical training and sports among rural population; investments in health-care institutions, gas supply networks, roads, seaports, development of financial services in rural areas, etc.

And the last, but not less important issue to be discussed in the framework of multifunctionality is the environmental status of Ukraine's agriculture. The natural conditions and climate in Ukraine are fundamentally favorable to agriculture. Ukraine's soil is widely recognized as a major national asset thanks to its tremendous fertility and outstanding agricultural qualities. According to data compiled by the State Committee for Statistics, agriculture currently occupies $72 \%$ and forests $17,2 \%$ of the total land area (60,4 million ha). However, the Ukraine is one of the countries that exemplify the seriousness of land degradation in the region as described in the Regional Implementation Annex for Central and Eastern Europe, of the Convention.

During the era of the Soviet Union, the mass intensification and expansion of agriculture resulted in soil degradation. In 1998 changes took place in the structure of land resources. In comparison with 1997, the area of arable land decreased by 27800 hectares, with the area of tillage being reduced by 223400 hectares. While some of these changes are the result of expansion of previously planted protective forest plantations and strips, silt-catching basins and river-bank reinforcements, most of the change has occurred due to the change of ownership and abandonment of previously intensively-tilled agricultural land. Through this, the redistribution of land has contributed to a considerable decrease in the amount of land conservation and restoration activities in the last decade. The ecologically sound proportion between areas of arable lands, pastures and forests has been neglected. Low productive plots, including river meadows, marginal lands and slopes were reclaimed into crop production without proper fertilization and up-keep. Antierosion measures, such as planting shelterbelts and terracing slopes have been almost non-existent in the last decade. The amount of irrigated lands has been decreasing due to the difficulties in their maintenance. With no recultivation and gradual deterioration of soil and water conservation systems after a long span of unsustainable practices, agricultural land faces a crisis with intensified erosion, nutrient depletion and loss of protective forest coverage. The annual rate of soil dehumification in Ukraine runs as high as 0,6 to 1,0 thousand hectares, and the eroded land area measures now $40 \%$ of the total territory. Up to 500 million tons of soil are washed from hillsides annually, which results in the loss of 11 million tons of humus, 500 thousand tons of nitrogen, 400 thousand tons of phosphorus and 700 thousand tons of potassium. The average annual rate of increment of eroded area is 80 thousand hectares. The negative balance of the soil nutrition elements reaches $100 \mathrm{~kg}$ per hectare and more, and nearly all the tillage soil is over-condensed. Serious concern arises from the fact that in some regions soil does not receive enough important microelements such as molybdenum, manganese, and iodine. The total environmental and economic damage is estimated at about 4 billion USD.

Another major concern of the environmental aspect of agricultural multifunctionality is the use of fertilizers in agriculture. In Ukraine the level of their use started to increase from the mid-1960s onwards. During the period from 1966 to 1970 an average of 1,4 million tonnes (or $46 \mathrm{~kg} / \mathrm{ha}$ ) of fertilizers were applied annually. In the second half of the 1980s this figure reached 4 to 4,7 million tonnes of fertilizers. The increase in the application rates of mineral fertilizers influenced favorably the yields of agricultural crops. After the collapse of the USSR, state financing was reduced at the time because of a general crisis in the Ukrainian economy. Private investment became the source of finance for fertilizer manufacturers. The exportation of fertilizers was the only means of covering the cost of reconstruction of the enterprises, due to the insolvency of the agro-industrial sector in Ukraine.

According to the official statistics, fertilizer consumption fell from 4,2 million tonnes of nutrients in 1990 (when admittedly fertilizer was excessively and wastefully applied) to 424 thousand tonnes in 1999. There is no shortage of mineral fertilizers in Ukraine and the fall is due to unfavorable economic conditions in agriculture. In 2002, 456 thousand tonnes of mineral fertilizer nutrients were applied (Figure 5) or 14,6 $\mathrm{kg} / \mathrm{ha}$. This is 28 percent more than in 2000 . The present consumption level of mineral fertilizers is very low compared with 1990, particularly in the cases of potash and phosphate. In 2005, nitrogenous fertilizers accounted for 72 percent (in 2000, 80,1 percent) of total nutrient consumption, phosphorus and potash for 18 percent ( 13,5 percent) and 10 percent $(6,4$ percent $)$ respectively. In 2004, mineral fertilizers were used on 45,5 percent of the total area under agricultural crops (6,4 million ha), while in 2000 less than a quarter of the sown area was fertilized.

Because of the sharp decline in the quantities of organic and mineral fertilizers applied on the majority of farms in Ukraine, the balance of nutrients has generally become negative. There has been a 5 to 13 fold decrease in the use of organic nutrients, mostly from manure, in the different zones of Ukraine. This has

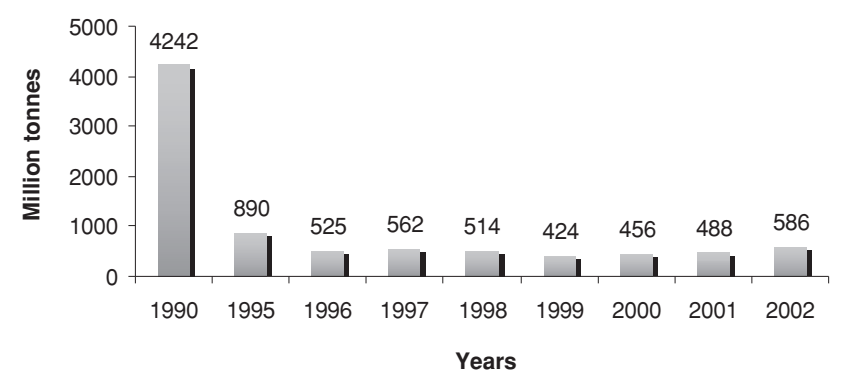

Figure 5. Fertilizer consumption in Ukraine Source: State Statistics Committee of Ukraine 
resulted in a sharp deterioration of the humus balance in the soil. Dehumification is of particular concern in Polissya region, where during the last 10 to 15 years the humus deficit has increased five times. In Ukraine as a whole, the balance of nutrients during the past decade has deteriorated sharply. In particular, the balance of nitrogen has changed from $-3,1$ to $41,5 \mathrm{~kg} / \mathrm{ha}$, phosphorus (P2O5) from $+24,9$ up to $-16,1 \mathrm{~kg} / \mathrm{ha}$ and potassium (K2O) from $-0,5$ to $-56,4 \mathrm{~kg} / \mathrm{ha}$. Besides more than 4 million tonnes of fertilizers, about 175000 tonnes of chemical pesticides are used annually in agriculture. Of 170 pesticides used in Ukraine, 49 are particularly harmful as highly toxic, supercumulative and stable. However, the tendency towards a decrease in the use of chemicals and an increase in the use of biological plant protection has begun to appear in Ukraine only in recent years. Since the current stage of the development of agriculture in the country is characterized by complications in the ecological situation, the government once again steps in and provides a support for agriculture. Spending on environment protection is precisely determined within the framework of the state programs, e.g. protection and effective use of forest and water resources etc.

\section{Conclusions}

Summarizing, it should be said that agriculture remains an important force in sustaining operation and growth of the whole Ukraine's economy. In 2008 this sector alone composed 16\% of the Ukraine's GDP and taking into consideration the resource potential of Ukraine's agriculture, it will most probably continue further expansion in the long run. Thus, $18,9 \%$ of the total are sod Europe's agriculture is concentrated in Ukraine, including 26,9\% of its arable land. According to FAO experts only $40 \%$ of agricultural potential in Ukraine is properly used. Specialist from World Bank has also positively evaluated the potential of the country and concluded that Ukraine's agricultural production can be doubled in case of proper management and suitable governmental support.

Hopefully, future growth of the agri-industrial sector, and consequently the increase in the budget sum, will make it possible to foster the development of the infrastructure and social-cultural sphere of the rural areas. Unfortunately, current situation is characterized only by existence of negative trends. Poor condition of streets and roads in villages, insufficient number of schools, hospitals, post-offices, libraries, etc, high unemployment rate and migration from rural areas of Ukraine represent only the top of the list. The condition of the countryside is neglected to a degree, where little improvement can be done without government intervention and financial support. State police should target the maintenance and dynamism of rural communities, since it's basic to sustaining agro-ecology and improving the quality of life of rural residents. Later on, more attention should be paid to social viability, which includes maintenance of the cultural heritage of the rural areas, since numerous societies in Ukraine still identify intensely with their historical origins in agrarian communities and rural lifestyles.
The environmental function of agriculture relates to land use and can have both beneficial and harmful effects on the environment. At this time there is a number of environmental problems observed in Ukraine. Improper use of the arable lands has exhausted them and was followed by soil degradation and its dehumification. These issues are often underestimated due to the large amount of arable lands in Ukraine. However, without accurate land management the country might soon find itself facing food crisis, since one of its major agricultural resources will be devastated.

The relative importance of the three aspects of the agricultural multifunctionality (economical, social and environmental) expressed in the article will depend on the future strategic choices at the local and national levels. Since the multiple functions of agriculture may be relevant at many scales, from local, over national and regional, to global, and operate over different horizons it is extremely important for Ukraine to integrate into global community and incorporate world experience in order to enjoy overall economic and environmental benefits of the country's multifunctional agriculture.

Additional research and analysis needs to be conducted on this subject to allow Ukraine to truly utilize its agri-industrial complex in the most efficient and effective means and aspire to its highest potential. Knowing and understanding the immense benefits of multifunctionality is key, and will inevitably lead to a more successful and prosperous future of Ukraine.

\section{References}

Artyushyn V. - Pugachov M.: Підприємництво в сільській місцевості в контексті подолання бідності, Kуіv 2009

Chapko I. - Kobuta I.: Сучасна політика підтримки сільського господарства в Україні, Kуiv, 2007

Food and Agriculture Organization of the United Nations: Fertilizer use by crop in Ukraine, Rome, 2005

Hryvniv L.: Country Report on the Present Environmental Situation in Agriculture - Ukraine. Department of Economics, Lviv State University, 2000

Institute for Economic Research and Policy Consulting in Ukraine: Rural Non-Farm Employment in Ukraine, Kyiv, 2005

Kyzyma I.: Determinants and Consequences of Female Labor Migration from Rural Areas: The Case of Ukraine, Kirovohrad National Technical University, 2008

Nivyevskiy O.: Fiscal Support to Agriculture in Ukraine, Kyiv, 2006

Sikachyna O. - Zhygadlo V.: perspectives of Agricultural Production Development: Ways and Development consequences, August 2007

Strubenhoff H. - Movchan V.: Політика України у сфері сільського господарства біоенергетики та харчової промисловості - дослідження, висновки та рекомендації, Kуіv, 2009

Sviatnenko V.: Ukraine Agriculture Sector Report, Kyiv, 2008

Ustenko O.: Features of the agricultural subsidies in Ukraine. Brandeis University, 2004 